\title{
DAYA TANGGAP KINERJA PELAYANAN PERPUSTAKAAN PADA DINAS PERPUSTAKAAN DAN KEARSIPAN KABUPATEN ENREKANG
}

\author{
Andi Ahmad Chabir Galib \\ Iskandar \\ La Ode Ismail Ahmad \\ Dinas Perpustakaan dan Kearsipan Kabupaten Enrekang \\ ahmadchabir@gmail.com
}

\begin{abstract}
Abstrak: Tujuan Penelitian ini adalah untuk menganalisis daya tanggap kinerja pelayanan perpustakaan pada Dinas Perpustakaan dan Kearsipan Kabupaten Enrekang. Penelitian ini adalah penelitian deskriptif kualitatif, yang berlokasi di Dinas Perpustakaan dan Kearsipan Kabupaten Enrekang dengan menggunakan pendekatan fenomenologi. Penelitian ini tergolong kualitatif, data dikumpulkan dengan menggunakan metode observasi, metode wawancara, dan metode dokumentasi. Teknik pengolahan dan analisis data dilakukan dengan melalui tiga tahapan, yaitu reduksi data, penyajian data, dan penarikan kesimpulan.

Hasil dari penelitian ini menunjukkan bahwa daya tanggap pelayanan perpustakaan di Dinas Perpustakaan dan Kearsipan Kabupaten Enrekang dalam memberikan pelayanan kepada pemustaka sudah cukup baik. Walaupun memang masih ada beberapa keluhan pemustaka terkait daya tanggap tersebut. Misalnya terkait letak koleksi dan pengadaan buku yang terlambat

Sebagai implikasi, Daya tanggap pelayanan perpustakaan pada Dinas Perpustakaan \& Kearsipan Kabupaten Enrekang perlu terus ditingkatkan agar keluhan pemustaka bisa diminimalisir.
\end{abstract}

\section{Kata Kunci: Daya Tanggap; Pelayanan Perpustakaan}

\section{PENDAHULUAN}

Perpustakaan sebagai salah satu lembaga pelayanan publik di era reformasi dan era digital ini, dituntut untuk dikelola lebih profesional. Oleh karena itu, kinerja pelayanan perpustakaan menjadi hal yang sangat penting guna menilai seberapa jauh layanan yang diberikan oleh perpustakaan dalam memenuhi harapan dan kepuasan masyarakat.

Disisi lain kinerja juga penting sebagai evaluasi untuk meningkatkan efisiensi dan efektivitas pelayanan perpustakaan. Dengan adanya penilaian terhadap kinerja tersebut, maka upaya untuk memperbaiki kinerja pelayanan perpustakaan bisa dilakukan secara teratur dan sistematis.

Perpustakaan sebagai lembaga pelayanan publik seharusnya berkewajiban menyediakan pelayanan yang terbaik bagi seluruh masyarakat. Didalam konsep Islam pun mengajarkan bahwa dalam memberikan layanan jasa janganlah 
memberikan yang buruk atau tidak berkualitas, melainkan yang berkualitas kepada orang lain. ${ }^{1}$ Hal ini tampak dalam QS al-Baqarah/ 2: 267:

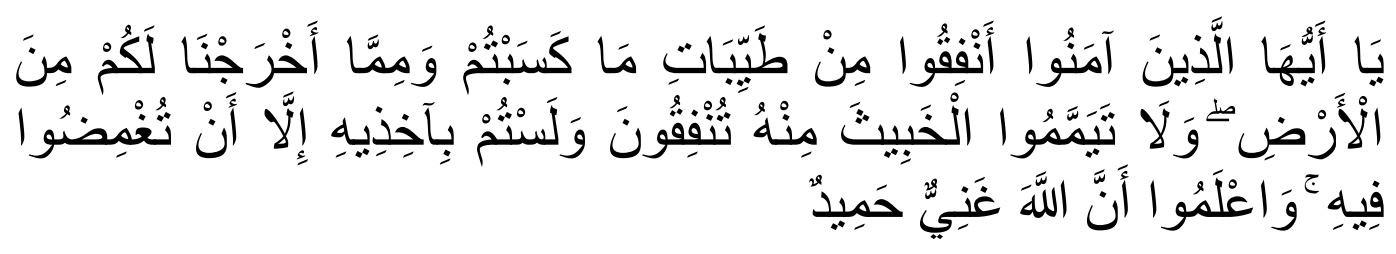

Terjemahnya:

"Hai orang-orang yang beriman, nafkahkanlah (di jalan Allah) sebagian dari hasil usahamu yang baik-baik dan sebagian dari apa yang kami keluarkan dari bumi untuk kamu. dan janganlah kamu memilih yang buruk-buruk lalu kamu menafkahkan daripadanya, Padahal kamu sendiri tidak mau mengambilnya melainkan dengan memincingkan mata terhadapnya. dan ketahuilah, bahwa Allah Maha Kaya lagi Maha Terpuji". ${ }^{2}$

Oleh karena itu, diperlukan perubahan yang mendasar terutama dalam hal peningkatan kualitas atau kinerja pelayanan perpustakaan yang lebih berorientasi pada kepuasan layanan masyarakat (customer service) dan tanggap terhadap dinamika lingkungan pelayanan, artinya berusaha untuk memberikan pelayanan yang terbaik dan mengevaluasinya berdasarkan sudut pandang penguna jasa perpustakaan. Selama ini sikap dan perilaku para penyedia layanan perpustakaan lebih berorientasi kepada kebutuhan lembaga dan atasan yang cenderung harus dilayani, sehingga mengabaikan pelayanan kepada pengguna.

Berkenaan dengan hal tersebut, kualitas atau kinerja pelayanan perpustakaan yang profesional perlu diwujudkan, selain itu petugas layanan sebagai sumber daya manusia di perpustakaan yang merupakan ujung tombak dalam memberikan pelayanan kepada pengguna juga dituntut untuk memberikan pelayanan yang berkualitas dan lebih berorientasi pada kepuasan pengguna, responsif terhadap tantangan dan peluang baru, tidak terpaku pada kegiatankegiatan rutin, memiliki kompetensi untuk memberikan pelayanan secara adil dan memiliki kemampuan untuk memberdayakan masyarakat sehingga dapat mewujudkan masyarakat yang memiliki tingkat literasi yang tinggi.

Dinas Perpustakaan dan Kearsipan Kabupaten Enrekang adalah salah satu lembaga yang menyediakan jasa pelayanan informasi tersebut. Sebagaimana diketahui bahwa dalam sebuah pelayanan perpustakaan ada dua hal yang harus saling mendukung yaitu institusi dan individu. Dua hal tersebut tidak bisa berdiri sendiri-sendiri, mereka saling keterkaitan dan saling mendukung dalam kegiatan

\footnotetext{
${ }^{1}$ Ridwan Aldursanie, Kualitas Pelayanan dalam Islam: http://ridwan202.wordpress.com/2013/02/11/kualitas-pelayanan-dalam-islam/.

${ }^{2}$ Kementerian Agama RI, Al-Qur'an dan Terjemahnya (Bogor, Dharma Art, 2007), h. 45.
} 
pelayanan. Institusi yang baik dan modern tidak akan berjalan pelayanan yang baik tanpa adanya individu handal yang mendukung. Begitu pula dengan individu yang handal tidak akan berhasil memberikan pelayanan yang baik tanpa adanya dukungan dari institusi, baik dukungan materi maupun moril. Jadi dua hal ini memang tidak bisa terpisahkan satu sama lain.

Dalam bidang jasa pelayanan perpustakaan dan informasi, Perpustakaan menyelenggarakan layanan jasa perpustakaan dalam bidang ilmu-ilmu sosial, humaniora, ilmu pengetahuan dan teknologi serta bidang lainnya. Salah satu bidang yang memberikan layanan informasi kepada masyarakat di perpustakaan adalah Bidang Layanan Koleksi Umum yang merupakan tempat yang paling banyak di kunjungi oleh masyarakat pencari informasi. Dengan banyaknya pencari informasi di Bidang Layanan Koleksi Umum ini, maka Dinas Perpustakaan dan Kearsipan Kabupaten Enrekang maupun petugas pelayanan pada layanan perpustakaan ini, dituntut untuk meningkatkan kinerjanya guna memberikan kualitas layanan yang baik kepada masyarakat. Namun dalam realitasnya, iklim layanan yang ada di Dinas Perpustakaan dan Kearsipan Kabupaten Enrekang belum sepenuhnya sesuai dengan harapan masyarakat. Pengembangan dan pemberdayaan perpustakaan belum maksimal serta layanan jasa perpustakaan belum menggembirakan. Fenomena yang ada adalah kinerja pustakawan dan pegawai serta tenaga kontrak dalam memberikan layanan belum sepenuhnya sesuai dengan harapan pengguna dan masyarakat, sehingga kualitas layanan perpustakaan masih perlu di tingkatkan.

Melihat realitas tersebut, maka peneliti akan mengkaji tentang bagaimana daya tangap kinerja pelayanan perpustakaan itu dapat berkembang secara efektif pada Dinas Perpustakaan dan Kearsipan Kabupaten Enrekang.

\section{KAJIAN TEORETIS}

\section{a. Daya Tanggap Kinerja Pelayanan Perpustakaan}

Responsivitas atau daya tanggap adalah kemampuan organisasi untuk mengidentifikasi kebutuhan masyarakat, menyusun prioritas kebutuhan, dan mengembangkannya ke dalam berbagai program pelayanan. ${ }^{3}$ Menurut Tjiptono (responsiveness) yaitu suatu kemampuan untuk membantu dan memberikan pelayanan yang cepat dan tepat kepada pelanggan, dengan penyampaian imformasi yang jelas. ${ }^{4}$ Daya tanggap merupakan suatu kebijakan untuk membantu dan memberikan pelayanan yang cepat kepada pelanggan. Fandi Tjiptono pun mengungkapkan pula bahwa responsiveness adalah keinginan para staf untuk membantu para pelanggan dan memberikan layanan dengan tanggap. ${ }^{5}$

\footnotetext{
${ }^{3}$ Atep Adya Barata, “Dasar-Dasar Pelayanan Prima: Persiapan Membangun Budaya Pelayanan Prima untuk Meningkatkan Kepuasan dan Loyalitas Pelanggan, Cet. 3, (Jakarta: Elex Media Kompotindo. 2008.), h. 27.

${ }^{4}$ Fandi Tjiptono. “Pemasaran Starategik”. (Jakarta: andi. 2007.), h. 69.

${ }^{5}$ Fandi Tjiptono. “Pemasaran Starategik”, h. 70.
} 
Dari beberapa pengertian responsiveness yang dikemukakan oleh para ahli, maka penulis menyimpulkan responsiveness adalah sikap peduli yang ditunjukkan oleh karyawan yang berupa respon terhadap segala keluhan atau masukan yang diberikan oleh member atau pelanggan.

\section{b. Faktor-faktor yang mempengaruhi daya tanggap (responsiveness)}

Responsiveness atau daya tanggap merupakan kemampuan jasa yang dilakukan langsung oleh penyelenggara layanan untuk memberikan pelayanan dengan cepat dan tanggap. Daya tanggap dapat menumbuhkan persepsi yang positif terhadap kualitas jasa yang diberikan. Termasuk didalamnya jika terjadi kegagalan atau keterlambatan dalam penyampaian jasa, pihak penyedia jasa berusaha memperbaiki atau meminimalkan kerugian pemustaka dengan segera. Dimensi ini menekankan pada perhatian dan kecepatan pengelola perpustakaan atau pustakawan yang terlibat untuk menanggapi permintaan, pertanyaan, dan keluhan konsumen.

Jadi, komponen atau unsur dari dimensi ini terdiri dari kesigapan pustakawan dalam melayani pemustaka, kecepatan pustakawan dalam melayani pemustaka, dan penanganan keluhan pemustaka. Dimana dalam hal ini ada beberapa faktor yang dapat mempengaruhi daya tanggap tersebut yaitu:

1. Spontanitas, dimana pustakawan menunjukkan keinginan untuk menyelesaikan masalah yang dihadapi oleh pemustaka.

2. Penyelesaian masalah, dimana pustakawan yang berhubungan langsung dengan pemustaka harus memiliki kemampuan untuk menjalankan tugas berdasarkan standar yang ada, termasuk pelatihan yang diberikan untuk dapat memberikan pelayanan yang lebih baik.

3. Perbaikan, dimana apabila terjadi hal-hal yang tidak diinginkan harus mempunyai personel yang dapat menyiapkan usaha-usaha khusus untuk mengatasi kondisi tersebut, seperti :

a) Mempercepat Pelayanan;

b) Pelatihan pustakawan;

c) Komputerisasi dokumen;

d) Penyederhanaan system dan prosedur;

e) Pelayanan yang terpadu (one-stop-shoping);

f) Penyederhanaan birokrasi;

g) Mengurangi pemusatan keputusan.

\section{c. Indikator daya tanggap (responsiveness)}

Daya Tanggap (Responsiveness) yaitu suatu kemauan untuk membantu dan memberikan pelayanan yang cepat (Responsif), dan tepat kepada pemustaka, dengan penyampaian informasi yang jelas. Membiarkan pemustaka tanpa adanya suatu alasan yang jelas menyebabkan persepsi yang negatif dalam kualitas pelayanan. 
Pustakawan harus tahu benar apa yang diinginkan oleh pemustaka. Untuk itu, pustakawan harus berkomunikasi dengan mereka, sehingga dapat mengetahui apa yang mereka inginkan. Untuk memenuhi keinginan mereka, pustakawan harus dapat menunjukkan bahwa ia dapat melayani mereka dengan baik. Lazimnya dengan cara memberikan pelayanan cepat, tepat, mudah, ramah dan professional sampai mereka akan puas. Perlu diingat bahwa mereka datang ke perpustakaan dengan membawa harapan, agar mereka dapat dibantu dan dilayani dengan baik, sehingga kesulitan mereka akan segera dapat terpecahkan.

Jika mereka merasa senang dan puas, mereka akan datang kembali ke perpustakaan. Oleh karena itu, pustakawan harus betul-betul mengetahui dan menguasai jenis-jenis layanan apa yang dibutuhkan oleh mereka. Selain itu, pustakawan harus mengetahui dan menguasai layanan yang ada di perpustakaan, sehingga pustakawan dapat memberikan penjelasan bagaimana mereka dapat menggunakan dan memanfaatkan layanan yang tersedia di perpustakaannya. Pustakawan professional selalu berusaha untuk mengetahui kemauan pemustakanya.

Dalam operasionalnya responsivitas dalam pelayanan perpustakaan dijabarkan menjadi beberapa indikator, seperti meliputi:

1. Terdapat tidaknya keluhan dari pemustaka;

2. Tanggapan penyelenggara pelayanan terhadap keluhan yang disampaikan pemustaka;

3. Tersedianya sarana pengaduan yang dapat digunakan oleh pemustaka dalam menyampaikan keluhan;

4. Petugas pelayanan cepat dalam memberikan bantuan kepada pemustaka yang menemui kesulitan dalam proses pelayanan;

5. Tersedianya informasi mengenai prosedur pelayanan, jam pelayanan, biaya pendaftaran anggota dan program-program pelayanan perpustakaan yang dibutuhkan pemustaka;

6. Program-program pelayanan yang melibatkan partisipasi pemustaka.

\section{d. Pengaruh daya tanggap (responsivitas) terhadap kepuasan pemustaka}

Membiarkan pemustaka menunggu, persepsi yang negatif dalam kualitas pelayanan. Menurut Tjiptono berkenaan dengan kesediaan dan kemampuan penyedia layanan adalah untuk membantu para pemustaka dan merespon permintaan mereka dengan segera. ${ }^{6}$

Setiap pustakawan dalam memberikan bentuk-bentuk pelayanan, mengutamakan aspek pelayanan yang sangat mempengaruhi perilaku orang yang mendapat pelayanan, sehingga diperlukan kemampuan daya tanggap dari pegawai untuk melayani masyarakat sesuai dengan tingkat penyerapan, pengertian, ketidaksesuaian atas berbagai hal bentuk pelayanan yang tidak diketahuinya.

${ }^{6}$ Fandy Tjiptono. “Service Management Mewujudkan Layanan Prima”. (Yogyakarta: Andi. 2012), h. 175. 
Hal ini memerlukan adanya penjelasan yang bijaksana, mendetail, membina, mengarahkan dan membujuk agar menyikapi segala bentuk-bentuk prosedur dan mekanisme kerja yang berlaku dalam suatu organisasi, sehingga bentuk pelayanan mendapat respon positif .

Suatu organisasi sangat menyadari pentingnya kualitas layanan daya tanggap atas pelayanan yang diberikan. Setiap orang yang mendapat pelayanan sangat membutuhkan penjelasan atas pelayanan yang diberikan agar pelayanan tersebut jelas dan dimengerti. Untuk mewujudkan dan merealisasikan hal tersebut, maka kualitas layanan daya tanggap mempunyai peranan penting atas pemenuhan berbagai penjelasan dalam kegiatan pelayanan kepada masyarakat.

Apabila pelayanan daya tanggap diberikan dengan baik atas penjelasan yang bijaksana, penjelasan yang mendetail, penjelasan yang membina, penjelasan yang mengarahkan dan yang bersifat membujuk, apabila hal tersebut secara jelas dimengerti oleh individu yang mendapat pelayanan, maka secara langsung pelayanan daya tanggap dianggap berhasil, dan ini menjadi suatu bentuk keberhasilan prestasi kerja.

\section{METODOLOGI PENELITIAN}

Jenis penelitian ini adalah penelitian deskriptif kualitatif. Penelitian ini berlokasi di Dinas Perpustakaan dan Kearsipan Kabupaten Erekang. Pendekatan dalam penelitian ini adalah pendekatan fenomenologi. Sumber data ada dua, yaitu sumber data primer dan sumber data sekunder.

Untuk memperoleh data yang sesuai permasalahan penelitian ini maka teknik yang penulis gunakan dalam pengumpulan data, yaitu melalui langkahlangkah sebagai berikut:

a. Observasi

b. Wawanacara (Interview)

c. Dokumentasi

Untuk menetapkan keabsahan data diperlukan teknik pemeriksaan. Uji keabsahan data dalam penelitian kualitatif meliputi uji credibility (validitas internal), transferability (validitas eksternal), dependability (reliabilitas), dan confirmability (obyektifitas). ${ }^{8}$ Dalam penelitian ini, pengujian keabsahan data yang digunakan adalah uji kredibilitas yaitu dilakukam dengan menggunakan teknik triangulasi dan member check.

${ }^{7}$ A. Valerie Parasuraman. (Diterjemahkan oleh Sutanto) "Delivering Quality Service". (New York; The Free Press. 2001), h. 52.

${ }^{8}$ Sugiyono, Model Penelitian Kuantitatif, Kualitatif, R \& D, h.366. 


\section{HASIL PENELITIAN DAN PEMBAHASAN}

Daya tanggap merupakan salah satu dimensi yang digunakan untuk mengukur kinerja pelayanan perpustakaan secara langsung dengan tujuan agar ada keselarasan antara program pelayanan perpustakaan dengan kebutuhan dan aspirasi masyarakat sebagai pengguna jasa.

Dalam menganalisis daya tangap petugas perpustakaan di bidang layanan, peneliti melakukan wawancara dengan berbagai informan.

Untuk mengetahui masalah apa yang dialami oleh pemustaka dalam penggunaan jasa layanan perpustakaan, peneliti melakukan wawancara dengan salah seorang informan yang berinisial $\mathrm{AH}$ :

"Saya pernah mencari buku untuk menyelesaikan tugas saya di kampus. Saya diarahkan oleh petugas perpustakaan untuk mencari di katalog online. Setelah saya menemukan di katalog letak buku yang ingin saya cari, saya kemudian menuju rak yang dimaksud. Tapi saya bingung karena buku tersebut tidak ada di rak yang dimaksud dalam katalog online. ",

Lebih lanjut, peneliti bertanya kepada $\mathrm{AH}$ untuk mengetahui apakah pemustaka menyampaikan keluhannya kepada pustakawan dan bagaimana sikap pustakawan menanggapi keluhan tersebut"

"Iya, ketika saya sudah merasa kesulitan mencari buku itu saya lalu mendatangi petugas perpustakaan dan meminta bantuan untuk mencarinya. Barulah petugas perpustakaan itu membantu saya dan itupun mereka sendiri agak bingung di mana letak buku tersebut, setelah kelilingkeliling akhirnya dia temukan di rak yang berbeda dengan yang disebutkan dalam katalog online. "10

Peneliti lebih lanjut melakukan wawancara dengan informan berinisial MA untuk mengetahui apakah pustakawan memberikan penjelasan kepada pemustaka tentang cara melakukan pengaduan (komplain) bila pemustaka kurang puas atas pelayanan yang diterima:

"Petugas perpustakaan memberitahu bagaimana cara kami melakukan pengaduan (komplain) bila kami merasa tidak puas atas pelayananan yang kami terima. Mereka menyediakan kotak khusus untuk tingkat kepuasan yang diletakkan di dekat pintu keluar, jadi kami bisa memilih apakah kami puas, kurang puas, tidak puas atau sangat puas. "11

Untuk mengetahui apakah di perpustakaan tersedia sarana pengaduan yang dapat digunakan oleh pemustaka, maka peneliti melakukan wawancara dengan informan RE:

\footnotetext{
${ }^{9}$ AH (23 tahun), Pemustaka, Wawancara, Enrekang, 05 Oktober 2018.

${ }^{10} \mathrm{AH}$ (23 tahun), Pemustaka, Wawancara, Enrekang, 05 Oktober 2018.

${ }^{11}$ MA (16 tahun), Pemustaka, Wawancara, Enrekang, 10 )ktober 2018.
} 
"Di perpustakaan tersedia kotak saran. Petugas perpustakaan menjelaskan bahwa jika ada keluhan silahkan masukkan di kotak saran. Jadi setiap saya ada kendala saya kemudian memasukkan di kotak saran. Tapi diantara beberapa kendala yang telah saya masukkan, saya rasa hanya sebagian saja yang ditanggapi oleh petugas perpustakaan. Buktinya ada saran yang saya sudah masukkan sejak lama tetapi ketika saya berkunjung lagi, kendala itu masih saya dapati. Contohnya yaitu mengenai ketersediaan buku yang sesuai kebutuhan.,"12

Kemudian peneliti ingin mengetahui bagaimana sikap petugas dalam memberikan bantuan kepada pemustaka, wawancara dengan $\mathrm{AH}$ pun peneliti lakukan:

"Petugas perpustakaan cukup tanggap jika kami ada masalah. Misalnya waktu saya mau mendaftar menjadi anggota perpustakaan kartu mahasiswa saya tertinggal di rumah padahal syarat untuk menjadi anggota harus menyertakan identitas kartu mahasiswa tetapi petugas pelayanan yang kebetulan saya kenal baik memberikan kemudahan dengan membolehkan mendaftar terlebih dahulu baru kemudian kartu mahasiswanya menyusul kemudian. ",13

Hal yang agak sedikit berbeda diungkapkan oleh RE:

"Saya dulu pernah mau meminjam buku tetapi saya lupa membawa kartu anggota, sehingga saya tidak diperbolehkan meminjam buku padahal buku itu sangat saya butuhkan untuk menunjang pekerjaan saya di kantor. Saya mau pinjam fotocopy juga tidak boleh karena memang saat itu saya tidak membawa sama sekali identitas. Akhirnya saya hanya mencatat bagian-bagian penting yang ada dalam buku itu. Petugas perpustakaan sebenarnya mengarahkan agar saya datang lagi besok harinya membawa kartu anggota saya, tetapi saya tidak datang karena esok harinya saya sangat sibuk di kantor. ",14

Tata tertib dan peraturan perpustakaan merupakan hal yang tidak kalah pentingnya untuk diketahui oleh pemustaka, maka untuk memastikan apakah tata tertib dan perturan sudah diketahui oleh pemustaka, peneliti melakukan wawancara dengan $\mathrm{AH}$ :

"Saya paham tentang tata tertib dan peraturan yang berlaku di perpustakaan ini, karena semua itu ada terpasang di papan informasi tepatnya di depan pintu masuk utama dan juga ada tata tertib di dalam ruang pelayanan ketika kami membacal meminjam buku. Adapun hal-hal lain yang belum ada di informasikan, tetapi ketika kami bertanya maka

\footnotetext{
${ }^{12}$ RE (33 tahun), Pemustaka, Wawancara, Enrekang, 10 Oktober 2018.

${ }^{13}$ AH (23 tahun), Pemustaka, Wawanvcara, Enrekang, 12 Oktonber 2018.

${ }^{14}$ RE (33 tahun), Pemustaka, Wawancara, Enrekang, 12 Oktober 2018.
} 
petugas perpustakaan cepat melayani kami dan menjelaskan secara detail sampai kami faham. "'15

Lebih lanjut, peneliti melakukan wawancara dengan MA tentang bagaimana mendapatkan informasi mengenai tata tertib dan peraturan perpustakaan:

"Saya pernah bertanya tentang tata tertib peminjaman buku kepada petugas perpustakaan, agak lama baru saya direspon. Ternyata ada yang tertempel tapi saya tidak lihat. Jadi mungkin petugas perpustakaan agak kesal saat itu. Jadi setelah itu, ketika saya ingin bertanya sesuatu saya perhatikan dulu di papan informasi baik-baik. Kalau ternyata memang tidak ada baru saya bertanya ke petugas perpustakaan. Takut kalau mereka kesal lagi sama saya, hehehee.

Terkait kegiatan bimbingan dan penyuluhan perpustakaan, peneliti ingin mengetahui apakah pemustaka pernah diikutkan atau tidak, peneliti kemudian melakukan wawancara dengan RE:

"Saya mengetahui tentang kegiatan bimbingan dan penyuluhan perpustakaan. Dan saya pernah mengikuti kegiatan tersebut pada Bulan Mei dulu. Menurut saya, kegiatan tersebut cukup memberikan bantuan kepada saya, karena memang saya sangat membutuhkan bimbingan itu agar ketika berkunjung ke perpustakaan saya tidak lagi kebingungan. ",17

Wawancara berikut dengan $\mathrm{AH}$ :

"Saya juga mengetahui tentang kegiatan itu dan acara itu terbuka untuk umum, tapi saat itu saya tidak sempat datang, karena bersamaan kegiatan saya di kampus. ",18

Peneliti melakukan wawancara dengan AH dan MA untuk mengetahui apakah perpustakaan melibatkan partisipasi pemustaka seperti pada penulisan artikel atau pemilihan pengunjung terbaik:

"Saya mengetahui dan juga pernah mengikuti kegiatan penulisan artikel yang diadakan di perpustakaan. Karena kebetulan saya berteman di FB dengan pegawai perpustakaan di sini. Jadi setiap ada kegiatan perpustakaan yang dia upload di FB saya pasti melihatnya.",19

"Saya dan beberapa teman dulu pernah ikut di kegiatan pemilihan pengunjung perpustakaan terbaik. Kalau tidak salah kegiatan itu dilaksanakan pas saat merayakan Hari Kunjung Perpustakaan. "20

\footnotetext{
${ }^{15} \mathrm{AH}$ (23 tahun), Pemustaka, Wawanvcara, Enrekang, 12 Oktonber 2018.

${ }^{16}$ MA (16 tahun), Pemustaka, Wawancara, Enrekang, 12 Oktober 2018.

${ }^{17}$ RE (33 tahun), Pemustaka, Wawancara, Enrekang, 15 Oktober 2018.

${ }^{18}$ AH (23 tahun), Pemustaka, Wawanvcara, Enrekang, 12 Oktonber 2018.

${ }^{19} \mathrm{AH}$ (23 tahun), Pemustaka, Wawanvcara, Enrekang, 17 Oktonber 2018.

${ }^{20}$ MA (16 tahun), Pemustaka, Wawancara, Enrekang, 17 Oktober 2018.
} 
Kemudian peneliti melakukan wawancara lebih lanjut dengan MA untuk mengetahui apakah pemustaka pernah dilibatkan didalam penyusunan kegiatan pelayanan perpustakaan:

"Saya pernah dilibatkan langsung dalam penyusunan kegiatan pelayanan perpustakaan. .,"21

Untuk mengetahui bagaimana tanggapan pustakawan terhadap keluhan dari pemustaka yang mengatakan bahwa letak buku di rak berbeda dengan yang tercantum di OPAC, maka peneliti melakukan wawancara dengan Saudara Mohd. Ardi Hatta yang bertugas di bagian pelayanan koleksi:

"Memang biasa ada buku yang letaknya tidak sama dengan yang tercantum di katalog Opac, ini disebabkan karena biasa ada pengunjung yang mengembalikan sendiri buku yang telah dibaca. Padahal kami sudah menginformasikan bahwa buku yang telah dibaca diletakkan saja di meja, nanti petugas yang mengembalikan. Tapi mungkin karena kurangnya perhatian pemustaka sehingga buku yang sudah mereka baca tetap dikembalikan sendiri dan bukan pada rak yag seharusnya mereka simpan.,"22

Lebih lanjut, Ibu Adrawati Achmad menanggapi tentang mengapa pemustaka yang berinisial RE tadi tidak diperbolehkan meminjam buku:

"Memang kami tidak bisa meminjamkan buku kepada siapa pun jika tidak dapat menunjukkan kartu anggota perpustakaannya. Dan ini sudah menjadi aturan baku di perpustakaan. Untuk dipinjam keluar guna difoto copy pun, pemustaka harus menyimpan identitas sebagai jaminan bagi kami petugas perpustakaan. "23

Kemudian Bapak Kadang, sebagai Kepala Bidang Pengembangan Bahan Pustaka, Pelestarian dan Layanan TIK, memberikan tanggapan mengenai ketidak tersediaan koleksi secara cepat jika sudah dipesan oleh pemustaka:

"Kami sudah berusaha semaksimal mungkin untuk menangani segala keluhan pemustaka, baik itu yang disampaikan secara langsung maupun yang mereka masukkan ke kotak saran. Tapi memang ada beberapa keluhan yang tidak bisa kami tangani secepat mungkin, misalnya tentang kebutuhan buku. Karena kami sudah ada jadwal untuk pengadaan buku setiap tahun, jadi tidak mungkin dalam waktu yang secepat itu semua keluhan pemustaka kami atasi. Tapi tetap akan kami prioritaskan jika memang sudah ada program pengadaan buku.,"24

\footnotetext{
${ }^{21}$ MA (16 tahun), Pemustaka, Wawancara, Enrekang, 17 Oktober 2018.

${ }^{22}$ Mohd. Ardi Hatta (25 tahun), Petugas Pelayanan, Wawancara, 18 Oktober 2018.

${ }^{23}$ Adrawati Achmad (49 tahun), Pustakawan, Wawancara, 18 Oktober 2018.

${ }^{24}$ Kadang K. (42 tahun), Kepala Bidang Pengembangan Bahan Pustaka, Pelestarian, dan Pelayanan TIK, Wawancara, Enrekang, 19 Oktober 2018.
} 
Ibu Herliany, Sebagai Kepala Bidang Pengembangan Sumber Daya Perpustakaan Dan Minat Baca, juga menanggapi tentang kegiatan-kegiatan perpustakaan yang melibatkan pemustaka:

"Kegiatan-kegiatan pelayanan yang melibatkan pengguna selalu disosialisasikan melalui; iklan media cetak, internet, penyebaran brosur/leflet, dan poster. Tahun 2018 ini kegiatan itu antara lain dalam bentuk: Program penyuluhan dan penyebaran informasi, terdiri dari kegiatan : Bimbingan pemakai Perpustakaan, Penyebaran informasi terseleksi, Dialog dan diskusi antara pemakai dan petugas pelayanan. Program penyelenggaraan lomba, yang terdiri dari kegiatan: Lomba pemilihan pengunjung terbaik, Lomba penulisan artikel tentang layanan Perpustakaan, Lomba dalam rangka hari kunjung perpustakaan. Dan lain-lain. "25

Berdasarkan wawancara yang peneliti telah lakukan dengan informan, maka peneliti dapat menganalisa bahwa daya tanggap Dinas Perpustakaan dan Kearsipan Kabupaten Enrekang dalam memberikan pelayanan kepada pemustaka sudah cukup baik. Walaupun memang masih ada beberapa keluhan pemustaka terkait daya tanggap tersebut.

Peneliti melakukan wawancara dengan petugas perpustakaan untuk mengklarifikasi mengenai beberapa keluhan pemustaka, dan pustakawan memberikan jawaban bahwa memang kadang ada beberapa hal yang dikeluhkan pemustaka, misalnya tentang letak koleksi yang berbeda di Opac dengan di rak, tetapi hal ini disebabkan oleh ulah pemustaka lain yang kadang tidak mengikuti aturan bahwa buku yang sudah dibaca mohon diletakkan di meja baca. Pemustaka mengembalikan sendiri buku yang telah dibaca, sehingga buku itu kadang mereka tempatkan di rak yang tidak seharusnya. Tetapi ketika pemustaka bingung mencari koleksi dan dia meminta bantuan kepada pustakawan maka pustakawan cepat memberikan bantuan. Keluhan lainnya terkait keterlambatan pemesanan buku, pustakawan memberikan klarifikasi bahwa hal itu terjadi karena adanya aturan tentang pengadaan bahan pustaka di Dinas Perpustakaan dan Kearsipan Kabupaten Enrekang, tetapi hal itu tetap diperhatikan untuk segera diatasi. Keluhan pemustaka juga mengenai prosedur peminjaman buku, pustakawan menanggapi bahwa memang sudah SOP jika pemustaka tidak dapat menunjukkan kartu anggotanya maka tidak bisa dipinjamkan buku.

Dinas Perpustakaan dan Kearsipan Kabupaten Enrekang menyediakn kotak saran sehingga pemustaka dapat menyampaikan jika ada keluhan dan saran. Kemudian pemustaka juga mudah untuk mendapatkan informasi mengenai prosedur pelayanan, jam pelayanan, biaya pendaftaran anggota dan program pelayanan lainnya. Pemustaka juga sering dilibatkan dalam kegiatan di perpustakaan.

\footnotetext{
${ }^{25}$ Herliany (55 tahun), Kepala Bidang Sumber Daya Perpustakaan dan Minat Baca, Wawancara, Enrekang, 19 Oktober 2018.
} 
Untuk lebih jelasnya, maka peneliti menjabarkan kesimpulan penelitian dalam tabel berikut:

\begin{tabular}{|c|c|c|}
\hline Variabel & Indikator & Temuan Lapangan \\
\hline ivitas & 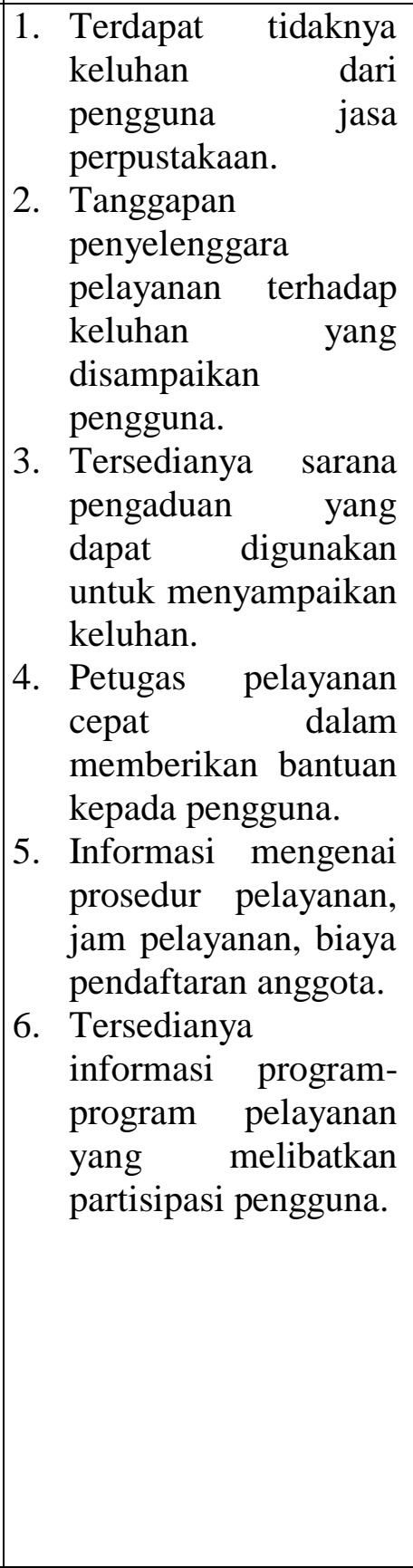 & $\begin{array}{l}\text { 1. Ada beberapa keluhan dari } \\
\text { pemustaka, misalnya terkait } \\
\text { letak koleksi yang berbeda di } \\
\text { rak dengan katalog OPAC. } \\
\text { 2. Pustakawan cukup tanggap } \\
\text { dalam menangani keluhan } \\
\text { pemustaka, walaupun memang } \\
\text { ada beberapa keluhan yang tidak } \\
\text { bisa ditangani secepat mungkin } \\
\text { karena adanya aturan yang } \\
\text { mengikat. } \\
\text { 3. Ada sarana yang disediakan } \\
\text { untuk pemustaka jika ada } \\
\text { keluhan atau pengaduan, yaitu } \\
\text { kotak saran. Jadi pemustaka } \\
\text { bebas mengaspirasikan } \\
\text { keluhannya terkait pelayan } \\
\text { perpustakaan. } \\
\text { 4. Pustakawan cepat dalam } \\
\text { memberikan bantuan kepada } \\
\text { pemustaka, walaupun memang } \\
\text { masih ada beberapa pustakawan } \\
\text { yang hanya membantu jika } \\
\text { diminta oleh pemustaka. } \\
\text { 5. Informasi mengenai prosedur } \\
\text { pelayanan, jam pelayanan dan } \\
\text { biaya pendaftaran anggota di } \\
\text { perpustakaan sudah cukup jelas. } \\
\text { 6. Tersedia informasi mengenai } \\
\text { program pelayanan dan } \\
\text { melibatkan partisipasi pengguna. } \\
\text { Informasi biasa disebarkan oleh } \\
\text { perpustakaan melalui media } \\
\text { iklan media cetak, internet, } \\
\text { penyebaran brosur/leflet, dan } \\
\text { poster. }\end{array}$ \\
\hline
\end{tabular}

\section{PENUTUP}

Berdasarkan pembahasan pada bab sebelumnya, maka hasil penelitian dapat ditarik kesimpulan bahwa daya tanggap pelayanan perpustakaan pada Dinas Perpustakaan \& Kearsipan Kabupaten Enrekang sudah cukup tanggap dalam 
menangani keluhan pemustaka, tata tertib juga sudah jelas bagi pemustaka. Kemudian pemustaka banyak dilibatkan dalam hal kegiatan pengembangan pelayanan perpustakaan. Walaupun memang ada yang tidak bisa ditangani secepat mungkin karena adanya aturan yang mengikat misalnya masalah pengadaan koleksi. Dan kadang juga ada koleksi yang tidak sesuai letaknya di rak dengan yang tercantum di katalog online, salah satu penyebabnya adalah karena ada pemustaka yang biasa mengembalikan sendiri buku di rak setelah dibaca.

Berdasarkan kesimpulan di atas, maka dapat disampaikan implikasinya Daya tanggap pelayanan perpustakaan pada Dinas Perpustakaan \& Kearsipan Kabupaten Enrekang perlu terus ditingkatkan agar keluhan pemustaka bisa diminimalisir.

\section{DAFTAR PUSTAKA}

Aldursanie, Ridwan, Kualitas Pelayanan Dalam Islam: http://ridwan202.wordpress.com/2013/02/11/kualitas-pelayanan-dalam-islam/.

Kementerian Agama RI, Al-Qur'an dan Terjemahnya. Bogor: Dharma Art, 2007.

Barata, Atep Adya, Dasar-Dasar Pelayanan Prima: Persiapan Membangun Budaya Pelayanan Prima untuk Meningkatkan Kepuasan dan Loyalitas Pelanggan, Cet. 3; Jakarta: Elex Media Kompotindo. 2008.

Tjiptono, Fandi, Pemasaran Starategik. Jakarta: andi, 2007.

Tjiptono, Fandy, Service Management Mewujudkan Layanan Prima. Yogyakarta: Andi, 2012. 